\title{
LUMBER YELD IN FUNCTION OF DIAMETER CLASSES AND QUALITY STANDARDS OF LOGS
}

\author{
Cícero Ramos Pereira da Silva ${ }^{1}$, João Vicente de Figueiredo Latorraca² ${ }^{2}$ Jair Figueiredo do Carmo ${ }^{3}$, \\ Pastor Amador Mojena ${ }^{4}$
}

\author{
${ }^{1}$ Forest Engineer, Consultoria Florestal, Sinop, MT, Brasil - icaraima @ gmail.com \\ ${ }^{2}$ Forest Engineer, Dr., Depto. de Produtos Florestais, UFRRJ, Seropédica, RJ, Brasil - latorraca@ufrrj.br \\ ${ }^{3}$ Forest Engineer, M.Sc., ICAA/UFMT, Sinop, MT, Brasil - carmo.jair@ gmail.com \\ ${ }^{3}$ Forest Engineer, Dr., ICAA/UFMT, Sinop, MT, Brasil - pamadormojena @ yahoo.com.br
}

Received for publication: 22/02/2013 - Accepted for publication: 08/04/2014

\begin{abstract}
The objective of this study was to determine and evaluate the yield of four (4) diameter classes in function of quality of logs, in logwood processing of Cedrinho (Erisma uncinatumWarm.). 20 logs of four diameter classes between 46 and $85 \mathrm{~cm}$ were selected and classified in terms of quality, being 5 logs for each diameter class. Diameter class I resulted in the lowest yield and diameter class III showed the highest yield. Yield increased according to the diameter of the logs in classes I, II and III. Class IV logs with larger diameters had quality defects such as cracks and internal flaws, causing a small yield drop. It could be concluded that there was a correlation between diameter and yield. Keywords: Mato Grosso; sawmill; native wood; correlation.
\end{abstract}

\section{Resumo}

Rendimento de madeira serrada em função de classes diamétricas e padrões de qualidade da tora. $\mathrm{O}$ objetivo deste trabalho foi determinar e avaliar o rendimento em diferentes classes diamétricas em função da qualidade das toras no desdobro do Cedrinho (Erisma uncinatum Warm.). Foram selecionadas e classificadas quanto à qualidade 20 toras em quatro classes diamétricas, entre 46 e 85 $\mathrm{cm}$, sendo cinco toras para cada classe diamétrica. A classe diamétrica I apresentou o menor rendimento e a classe diamétricaIII apresentou o maior. O rendimento aumentou de acordo com o diâmetro das toras na classe I, II e III. As toras da classe IV, com maiores diâmetros, apresentaram baixa qualidade, com defeitos como rachaduras e falhas internas, causando uma pequena queda no rendimento. Pode-se dizer que existe uma correlação entre diâmetro e rendimento.

Palavras-chave: Mato Grosso; serraria; madeira nativa; correlação.

\section{INTRODUCTION}

Brazil is the greatest tropical sawn wood producer and consumer, and the fifth exporter. In 2008, according to the International Tropical Timber Organization (Organizacion Intenacional de Las Madeiras Tropicales, (OIMT), 2010), the country produced 15.455 million cubic meters of timber, and according to Sociedade Florestal Brasileira (SFB), 2010 the Brazilian Amazon region holds an estimated timber volume of 106.388 million cubic meters.

Mato Grosso state is the second greatest native timber producer of the Amazons, its forest industry is responsible for the economy of several municipalities in the northern region of the state. In 2009, timber production areas existing in Mato Grosso state (center, north and northwest), were home to 20 logging centers. The 592 existing factories consumed four million cubic meters of timber and generated about 57 thousands direct and indirect jobs in that same year. Timber worked volume was approximately of 1.8 million cubic meters, generating a gross revenue of US\$ 803 million (about 1.6 billion R\$) (PEREIRA et al, 2010).

Seen in these terms, it is worth to highlight that wood industrial activity was more intense in the northeastern region of the state ( $12 \%$ of log consumption), whose main centers were the cities of Colniza, 
Aripuanã and Juara; and the central region of the state (11\%), with Sinop and Feliz Natal as the most important centers (SFB and IMAZON, 2010).

Between 2006 and 2010, Cedrinho (Erisma uncinatum Warm.), represented 12.3\% of the most commercialized species in the state. According to Secreteria do Estado de Meio Ambiente (SEMA), 2011, in this same period the most commercialized products were: lumber, planned lumber in two and four faces, manufactured products, wood turned veneers, sliced wood veneers, wood chips and off cuts, exploitation of wood blocks.

Cedrinho is characterized by $0.59 \mathrm{~g} / \mathrm{cm}^{3}$ apparent density at $15 \%$, considered as medium density, and finds application in naval and civil construction, production of furniture, basic carpentry and fabrication of plywood, doors, frames, baseboards, packages, clapboards, slats, molds for concrete, broomsticks, boards, boxes, crates and others (LORENZI, 1998).

According to Latorraca (2004), yield or exploitation percentage basically depends on the total volume of timber in logs used by sawmills, type of sawing process, final dimensions of the desired part (number of cuts made), type of machinery and type of labor (specialized or not).

According to Carmo (1999), the low yield of Brazilian sawmills is directly related to defects and consequent losses caused by the industrial process. This aspect gets even more serious verifying that machinery used for the primary logs breakdown in the Amazon region sawmills is old and, in great majority, under-dimensioned, causing cutting variations extremely higher than a good quality cutting would require.

Viadurre (2006), points out that sawing process method is one of the variables affecting lumber yield. Inadequate sawing process may have as consequence great losses in volume or quality loss of the produced lumber (FONTES, 1994).

Quality of logs to be worked has influence on lumber yield and reflects over the entire production chain (HOCHHEIM; MARTIN, 1993). Some criteria to be adopted for logs classification can be found in Brazil. According to standards for measuring and classification of hardwood logs, classification is made according to general shape, visible defects and abnormalities on revolving surface or on extremities (tips) and on calculation of liquid volume, and are classified according to the following ranking: Superior class, class I, class II, class III and class IV (INSTITUTO BRASILEIRO DE DESENVOLVIMENTO FLORESTAL (IBDF), 1984), today's IBAMA.

The Conselho Nacional de Meio Ambiente (National Environmental Council) (CONAMA), 2009 and SEMA, 2010, indicate volumetric yield of $45 \%$ when the question is transformation of tropical hardwood species logs into lumber. This estimated yield creates problems to the wood industry, because some species actually present yields above $45 \%$.

Therefore, a company must present a technical report on these species to a competent environmental organization and, after technical evaluation of this organization confirming the prospected quantities, those indexes will be customized for the company. In the case of Sinop, MT, where raw matter is getting every time more distant from sawmills, knowledge of yield that each species can provide is important for planning the acquisition of logs to be transformed into lumber.

In this study, the cedrinho species was chosen due to its economic importance in the region, with the greatest commercialization percentage among the traded species in the state. Main objective was to evaluate yield of Cedrinho (Erisma uncinatum) in transformation from logs to lumber, starting from different diametric classes, according to logs quality classified according to the standard of measuring and classification of hardwood logs (IBDF, 1984).

\section{MATERIALS AND METHODS}

This study was conducted in the firm L.G. Madeiras LTDA, a midsize sawmill, with a production between 500 and $1000 \mathrm{~m}^{3} /$ month of lumber, located in the municipality of Sinop, MT, in the

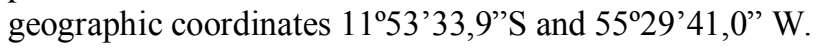

All logs used by the company are acquired by suppliers who apply forest management plans and are located at a distance of approximately 150 kilometers from Sinop, MT.

The company owns a band sawing machine with diameter of 1.25 meters for initial sawing of $\operatorname{logs}$ and a standard sequence of circular saws for rectification and cutting of raw parts. 
Vital (2008) considers yields of $55-56 \%$ as normal in conifers, and from 45 to $55 \%$ in hardwood species. According to the same author, yield calculation can be made using equation 1 .

$$
R=\frac{M}{T} \times 100
$$

where : $\mathrm{R}=$ Yield percentage of lumber

$\mathrm{M}=$ Volume of lumber, in $\mathrm{m}^{3}$

$\mathrm{T}=$ Volume of timber, in $\mathrm{m}^{3}$.

20 logs were selected in the sawmill deposit, belonging to four different diametric classes, being 5 logs per each class.

Each log was numbered to facilitate identification during the sawing process and diametric class was also identified, being: Number I for class between 45.0 and $56.0 \mathrm{~cm}$; Number II for class between 56.0 and $65.0 \mathrm{~cm}$; Number III for class between 65.0 and $75.0 \mathrm{~cm}$; Number IV for class between 76.0 and $85.0 \mathrm{~cm}$. Following that, logs were classified according to IBDF (1984) standard.

The formula of Smalian was used to obtain logs volume, such that by the mean diameter calculated from base and top of logs and with their lengths, it is possible to determine the volume of each one of them.

$$
\mathrm{V}=\frac{\pi}{40000} *\left(\frac{D 1+D 2}{2}\right)^{2} * \mathrm{~L}
$$

where: $\quad \mathrm{V}=$ volume of $\log \left(\mathrm{m}^{3}\right)$

$\mathrm{D} 1=$ diameter of the larger end or extremity $1(\mathrm{~cm})$

$\mathrm{D} 2=$ diameter of the smaller end or extremity $2(\mathrm{~cm})$

$\mathrm{L}=$ length of $\log (\mathrm{m})$.

Sawing process adopted in the company is tangential cutting parallel to the longitudinal axis, with retirement of slabs, to produce semi-blocks. Next, planks are produced which pass through a desk circular sawing machine, being worked in various widths, then they are transformed into beams, rafters and slats.

To obtain volume of lumber, all the produced parts (planks, beams, rafters, slats etc.) were separated and identified according to the number of each $\log$, and their thickness, width and length were measured with measuring tape and caliper. Volume of lumber was determined according to equation 3 :

$$
V=E \times L \times C
$$

where: $\quad \mathrm{V}=$ volume of lumber $\left(\mathrm{m}^{3}\right)$

$\mathrm{E}=$ thickness of the part $(\mathrm{m})$

$\mathrm{L}=$ width of the part $(\mathrm{m})$

$\mathrm{C}=$ length of the part $(\mathrm{m})$.

A simple statistical analysis was conducted by comparison of means, based on the analysis of variance and the Tukey range test at $95 \%$ of probability. Analyzed variables were: yield in function of diametric classes, and the Pearson correlation coefficient was also calculated between timber diameter and yield as lumber.

\section{RESULTS AND DISCUSSION}

Table 1 shows yield results as lumber of the species E. uncinatum in its respective diametric classes. It is verified that the lowest yield was given by diametric class I and the highest was by diametric class III and it is notable a significant difference between diametric classes I and III.

It is important to highlight that Biasi (2005), analyzing yield and efficiency in sawing process of three tropical species in Sinop, MT, with diametric classes between 31 and $70 \mathrm{~cm}$, obtained average yield 
of $59.83 \%$, varying between $57.30 \%$ and $62.40 \%$. However, according to Rocha (2002), sawing process yield varies between 45 and $55 \%$ in hardwood species.

Oliveira et al. (2003), found average yield of $49.28 \%$ in fifteen different native species, studying three sawmills in the municipality of Jaru, RO. Santos (1986) found a yield of 52.80\% in sawmills of the Amazonas State.

Table 1. Lumber yield as a function of diameter class.

Tabela1. Rendimento em madeira serrada em função da classe diamétrica.

\begin{tabular}{lcccc}
\hline \multirow{2}{*}{ Yield of lumber } & \multicolumn{4}{c}{ Diametric classes } \\
\cline { 2 - 5 } & I & II & III & IV \\
\hline Mean* $(\%)$ & $56.84 \mathrm{a}$ & $58.22 \mathrm{ab}$ & $61.1 \mathrm{~b}$ & $60.57 \mathrm{ab}$ \\
Coefficient of variation $(\%)$ & 4.90 & 3.04 & 1.76 & 3.19 \\
\hline
\end{tabular}

* Means followed by the same letter have no statistical significant difference at $95 \%$ level of probability.

Results of table 1 present $59.19 \%$ average yield out of the four diametric classes studied. This value, as it can be verified, was greater than values found by Oliveira et al. (2003), Santos (1986), CONAMA (2009) and SEMA (2010).

Furthermore, the $20 \operatorname{logs}$ presented defects at the evaluation for classification, like bending, hollows and buttresses, diametrical and not diametrical cracks. Thus, $20 \%$ of logs were classified as belonging to superior class, $65 \%$ class I and $15 \%$ class II.

Vianna Neto (1984), studying sawing techniques for eucalyptus, in small diameter logs, concluded that yield increased according to increase in diameter of the worked timbers, and that quality of the raw matter may influence up to $70 \%$ the results when looking for optimal yield.

Figure 1 shows that yield increased according to increases in diameter of logs, following a tendency. This yield was greater in good quality logs (Superior), confirming information from Vanna Neto (1984).

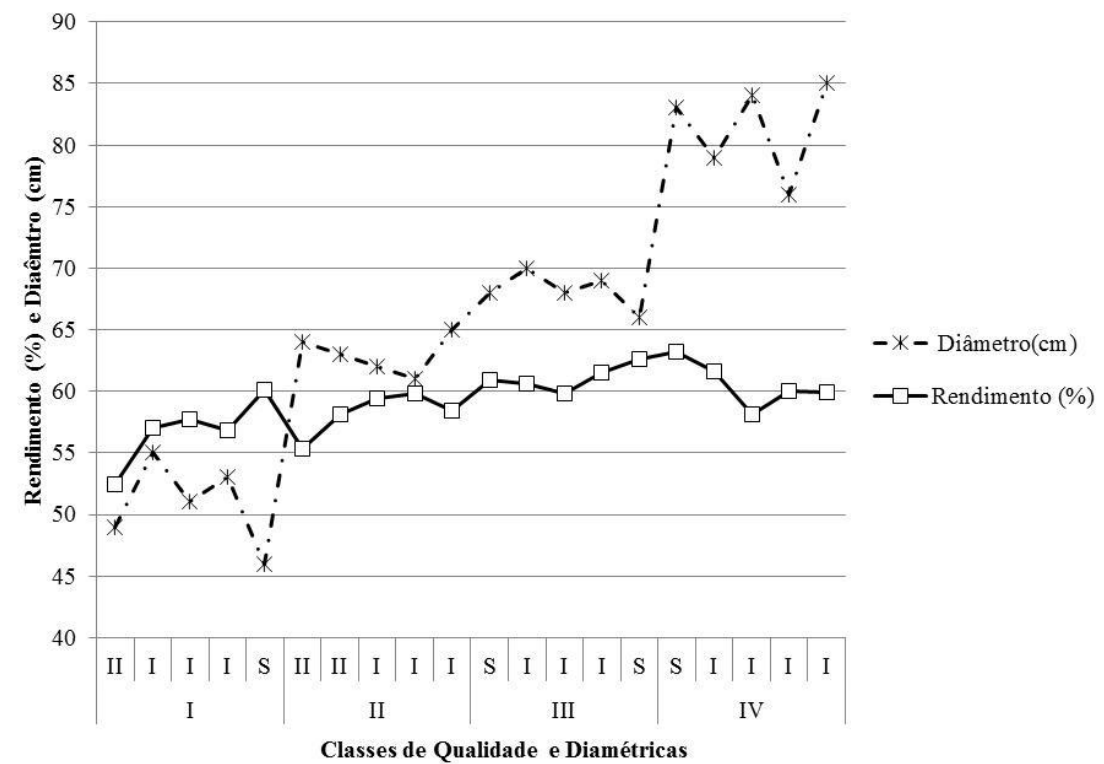

Figure 1. Comparative graph of yield, diameter and quality of logs in classes I, II, III and IV.

Figura 1. Gráfico comparativo entre rendimento, diâmetro e qualidade das toras nas classesI, II, III e IV.

Diametric class I resulted in the lowest yield (56.84\%). Rocha (2000) observes that smaller logs normally give lowest yields during the sawing process. Diametric class II, even without any Superior quality $\log$, gave a good yield. This is due to the few defects found in the external rolling surface, which also impair the yield. 
Diametric class III presented the best average yield, when compared to the rest (61.10\%). Logs of this class presented few or almost no defects. Diametric class IV, even with a greater diameter than the others, gave smaller yield than class III, due to the fact that logs of this size presented defects like cracks and internal hollows, appeared during the sawing process, resulting in a small yield reduction.

It is possible to say that yield diminishes together with logs quality reduction, this because of defects that are eliminated during the sawing process of low quality logs (EGAS, 2000).

Biasi (2005), studying the sawing process of cedrinho in four diametric classes from 31.0 to 70.0 $\mathrm{cm}$, found a gradual yield increase in diametric classes 1,2 and 3, while in class 4 there was a decrease from class III yield. According to this author, the determining factor for the yield drop were due to action of xylophagous agents in the greatest diameter logs of this species. In its work, the author did not follow any quality classification standard for the logs studied.

The Pearson's correlation coefficient between variables diameter $(\mathrm{cm})$ and yield $(\%)$ (Figure 2), gave a value of $0.552(\mathrm{p}<0.05)$, indicating that there was positive correlation between the studied variables, that is to say the greater the diameter, the greater will be the yield.

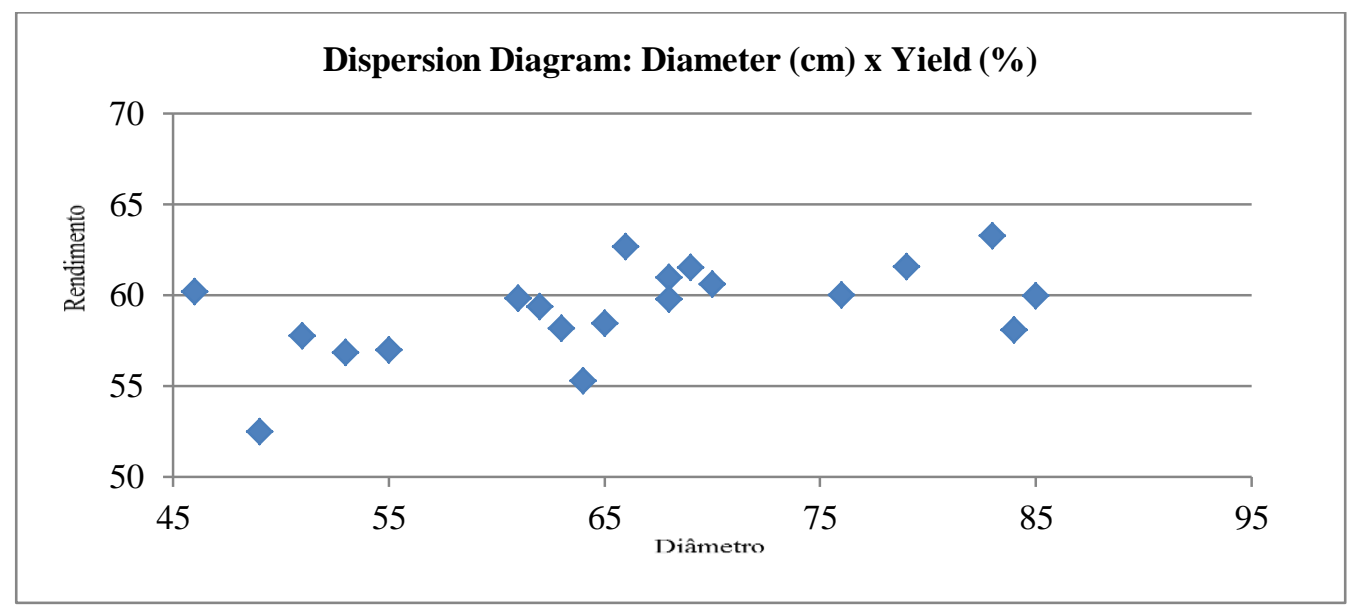

Figure 2. Correlation Diameter x Yield.

Figura 2. Correlação Diâmetro x Rendimento.

In this study, best yields were given by logs classified as Superior and the worst yields were given by $\operatorname{logs}$ with class I and II quality. To obtain yield increase together with the increase in $\log$ diameters, they must belong to good quality standard classes.

\section{CONCLUSIONS}

- Basing on this study it was concluded that there was tendency to increase yield in lumber following the increase of log diameters, but this result was strongly depending on the quality class of logs.

- Yield obtained was greater than $45 \%$, value established by CONAMA and SEMA-MT. Thus, it is very important for the wood industries to perform the classification process of logs (diameter and quality) before the first steps of the sawing process, to achieve the yield values required by legislation.

\section{REFERENCES}

BIASI, C. P. Rendimento e eficiência no desdobro de três espécies tropicais. 61 f. Dissertação (Mestrado em Tecnologia e Utilização de Produtos Florestais) - Universidade Federal do Paraná. Curitiba, 2005.

CARMO, J. F. Utilização e Manutenção de Serra de Fita. 72 p. Curso de Especialização em Administração e Processamento Madeireiro, Universidade Federal Rural do Rio de Janeiro, Seropédica, 1999. 
CONSELHO NACIONAL DO MEIO AMBIENTE (CONAMA). Resolução n⿳4十11, de 06 de maio de 2009. DOU no 86, em 08/05/2009, p. 93 - 96.

EGAS, A. F. Noções sobre a produção de madeira serrada. Maputo: UEM. 2000. 98 p.

FONTES, P. J. P. Auto-suficiência energética em serraria de Pinus e aproveitamento dos resíduos. 104 f. Dissertação (Mestrado em Tecnologia e Utilização de Produtos Florestais) - Universidade Federal do Paraná. Curitiba, 1994.

HOCHHEIN, N.; MARITN, P. Influência da qualidade das toras no processo de fabricação, rendimento, custo e rentabilidade da madeira serrada. In: $1^{\circ}$ Congresso Florestal Panamericano e $7^{\circ}$ Congresso Florestal Brasileiro (1993: Curitiba). Anais. Curitiba, PR SBS-SBEF, p. 644 - 646. 1993.

INSTITUTO BRASILEIRO DE DESENVOLVIMENTO FLORESTAL (IBDF). Normas para medição e classificação de toras de madeiras de folhosas. Brasília: 1984. 42 p.

LATORRACA, J. V. F. Processamento mecânico da madeira. Seropédica: Universidade Federal Rural do Rio de Janeiro, 2004. 116 p.

LORENZI, H. Árvores Brasileiras: manual de identificação e cultivo de plantas arbóreas nativas do Brasil. 2 ed., Vol. 2. Nova Odessa, SP: Editora Plantarum, 1998.

OLIVEIRA, A. D. de; MARTINS, E. P.; SCOLFORO, J. R. S.; REZENDE, J. L. P.; SOUZA, A. N. de. Viabilidade econômica de serrarias que processam madeira de florestas nativas: o caso do município de Jaru, estado de Rondônia. Cerne, Lavras, v. 9, n. 1, p. 1 - 15, 2003.

ORGANIZACIÓN INTERNACIONAL DE LAS MADERAS TROPICALES (OIMT). 2010. Reseña anual y evaluación de la situación mundial de las maderas. Yokohama, Japón. 208 p.

PEREIRA, D.; SANTOS, D.; VEDOVETO, M.; GUIMARÃES, J.; VERÍSSIMO. A. Fatos florestaisda Amazônia, 2010. Belém: IMAZON, 2010, 124 p.

ROCHA, M. P. Eucalyptus grandis Hill ex Maiden e Eucalyptus dunnii Maiden como fontes de matéria prima para serrarias. $185 \mathrm{f}$. Tese (Mestrado em Tecnologia e Utilização de Produtos Florestais) - Universidade Federal do Paraná. Curitiba, 2000.

ROCHA, M. P. Técnicas e planejamento em serrarias. Ed. rev. ampl. Curitiba: Fundaçăo de Pesquisas Florestais do Paraná, 2002. 121 p.

SANTOS, J. Situação da indústria madeireira no município de Manaus (1981 e 1983) e das serrarias no estado do Amazonas (1981). 1986. 78 f. Dissertação (Mestrado em Manejo Florestal) - Universidade Federal do Paraná, Curitiba, 1986.

SERVIÇO FLORESTAL BRASILEIRO (SFB). Florestas do Brasil em resumo - 2010: dados de 20052010. Brasília: 152 p.

SECRETARIA DE ESTADO DO MEIO AMBIENTE DE MATO GROSSO (SEMA-MT) 2011. Gestão Florestal. Disponível em: http://www.sema.mt.gov.br/. Acesso em: 19/02/2013.

SECRETARIA DE ESTADO DO MEIO AMBIENTE DE MATO GROSSO (SEMA-MT). Portaria $\mathbf{n}^{\mathbf{0}}$ 96 de 18/06/10.

SERVIÇO FLORESTAL BRASILEIRO (SFB); Instituto do Homem e Meio Ambiente da Amazônia (IMAZON). A atividade madeireira na Amazônia Brasileira: produção, receita e mercados. Belém. 2010. 20 p.

VIDAURRE, G. B. Efeito dos parâmetros do dente da serra de fita na qualidade e produtividade da madeira serrada de eucalipto, 71 p. Dissertação - Mestrado. Programa de Pós-graduação em Ciência Florestal - Universidade Federal de Viçosa. Viçosa, 2006.

VIANNA NETO, J. A. Considerações básicas sobre desdobro de Pinus spp. Silvicultura, 1984; 9(34): 15 - 19.

VITAL, B. R. Planejamento e operação de serrarias. Viçosa, MG: UFV, 2008. 211 p. 